\title{
Sex Determination from the Humerus Bone in Iranian Cases
}

\author{
Determinación del Sexo a Partir del Húmero en Casos Iraníes
}

Mahdi Hamzehtofigh'; Parvindokht Bayat $^{2}$ \& Rezvan Rahimifar ${ }^{1}$

HAMZEHTOFIGH, M.; BAYAT, P. \& RAHIMIFAR, R. Sex determination from the humerus bone in Iranian cases. Int. J. Morphol., 37(4):1370-1374, 2019.

SUMMARY: Sex determination from bones is of vital importance in anthropological studies and medico-legal cases. The present study focused on measurements of the humerus, and evaluation of the differences in sex present in the morphology through statistical analysis. In our study, 61 dry adult humerus bones of known sex (35 males and 26 female) were studied. Damaged bones were excluded from the study. Each humerus was measured for 10 parameters; measurements were taken by using a sliding caliper as described in anthropology textbooks and previous studies. The osteometric data of the humerus of the present study is statistically analyzed and in both sexes are compared. Statistical tests were applied to the metrical data obtained to assess whether the differences between the means of each parameter are statistically significant between male and female. We found more discriminatory parameters for the identification of sex from humerus. In this study we found in men positive correlations between AR and epicondylar width $(0.471 * *)$ and midshaft with length of humerous $(0.481 * *)$; the correlation of these parameters was not found in females. Conversely we found in female, positive correlations between medial and lateral angle with mid shaf t circumference $(0.488 * *)$ and width of epicondylar and maximum length $(0.511 * *)$ and medial angle, with medial and lateral angle $(0.498 * *)$ and maximum width with length of humerous $(0.512 * *)$; correlation of these parameters were not observed in males. In previous studies authors did not analyze relationship between total humeral length and the measurements of their segments related to possible differences among populations, by sex separately. This may be due to genetic, nutritional and socio-economic differences in the individuals or may be due to hypo masculinity in female humerus and hyper masculinity in male humerus.

KEY WORDS: Sex determination analysis; Humerus; Anthropometry.

\section{INTRODUCTION}

Sex determination is the first essential step for positive identification when a decomposed body is recovered. It is essential to identify sex from different bones of the body, other than the skull or pelvis. The humerus has rarely been tapped as a site for sex determination, though it has often demonstrated an even greater accuracy than other long bones such as the femur (Liu, 1989; Kothandaraman et al., 2014). It is an established fact that, standard metrical values derived for sexing the skeleton in one region if applied to the other region may not give $100 \%$ accuracy. Therefore it is imperative to obtain standard metrical values which are specific to a region (Kshirsagar et al., 2009). Therefore, the purpose of this research was to establish osteometric standards for the determination of sex from the humerus in center of Iran.

These recent studies suggest that the skeletal biology of South Africans is different from others and standards based on geographically distant populations like those of North Americans and Europeans may not provide the most reliable results (Steyn \& Iscan, 1997, 1998; Iscan $\&$ Steyn, 1999). The purpose of this study is to develop discriminant function formulas for determining sex, using commonly taken osteometric dimensions from the humerus of central of Iran (Iranian population). For more information of the different races to be able to obtain reliable results.

\footnotetext{
${ }^{1}$ Student research committee, Faculty of Nursing, Arak University of medical sciences, Arak, Iran.

${ }^{2}$ Department of Anatomy, Faculty of Medical, Arak University of medical sciences, Arak, Iran.
} 


\section{MATERIAL AND METHOD}

In the present study, 61 adult humruses of known sex (35 males and 26 females) from central Region of Iran were studied. The following measurements were taken.

Length: measured by using the osteometric board.

Epicondylar width: the maximum distance between medial and lateral epicondyles was measured by vernier calliper.

Midshaft circumference: the circumference of the shaft in the middle was measured with the help of a millimeter graph paper.

Vertical diameter of the head: was taken in the plane of the tip of greater tuberosity, as maximum distance between two points on the head of humerus, with the help of vernire calliper.

Humeral aspect ratio (AR): was calculated as humerus width divided by length and then multiplied by 100 , so the $\mathrm{AR}$ is the humerus width expressed as a percentage of humerus length.

\section{RESULTS}

As shown in Table I, means of Maximum of Width / MAX of Length $* 100$ (the humeral aspect ratio $=\mathrm{AR}$ ) were $3.47 \pm .31$, and the length of humerus $300.75 \pm 1.88 \mathrm{~mm}$, and there were means of midshaft circumference was $60.51 \pm .58 \mathrm{~mm}$, and means of epicondylar width was $56.72 \pm 4.05 \mathrm{~mm}$, angle of lateral wall was $124.30 \pm 16.51$ degree, angle of medial wall was $63.45 \pm 18.58$ degree, angle of medial and lateral wall was $61.04 \pm 17.2$ degree, maximum of depth was $6.11 \pm .71 \mathrm{~mm}$, maximum of width was $10.06 \pm .10 \mathrm{~mm}$ totally.
As shown in Table II the length of humerus ranged from $300.50-35.60 \mathrm{~mm}$ and mean is $320.07 \pm 1.14 \mathrm{~mm}$ in male and $260.90-300.40 \mathrm{~mm}$ and mean is $280.99 \pm 1.05 \mathrm{~mm}$ in females. It was observed that the AR for males was $3.40 \pm .29$ and $3.56 \pm .32$ in females respectively. There were significant differences between means of these parameters in male and female cases (0.05).

As shown in Table II, the epicondylar width of humerus ranged from 48.00-64.00 and means are 58.37 \pm 3.46 $54-69 \mathrm{~mm}$ in males and $49-62 \mathrm{~mm}$ and $54.51 \pm 3.77 \mathrm{~mm}$ in females. There were significant differences between means of these parameters in male and female cases (0.001).

As shown in Table II, the midshaft of humerus ranged from $50.70-70.90 \mathrm{~mm}$ and mean $60.76 \pm 567 \mathrm{~mm}$ in males and in females ranged from $50.20-70.10 \mathrm{~mm}$ and mean $60.19 \pm .45 \mathrm{~mm}$. There were significant differences between this parameter in male and female cases $(0.001)$.

As shown in Table II, the depth of bicipital groove of humerus ranged from $4.50-7.50 \mathrm{~mm}$ and mean was $6.24 \pm 74$ $\mathrm{mm}$ in males and in females ranged from $4.30-7.50 \mathrm{~mm}$ and mean was $5.93 \pm .64 \mathrm{~mm}$. There were significant differences between this parameter in male and female cases (0.0029).

As shown in Table III, there were maximum correlations between AR and width of humerus in two sexes (female $=0.932 * *$, male $=0.922 * *$ ), and between midshaft circumference and width of humerus in two sexes (female $=0.661^{* *}$, male $=0.591^{* *}$ ).

As shown in Tables III and IV, the relationship between the characters of humerus bone in men and women investigated separately. As mentioned above, there were relationships between some characters in two sexes, but it is different in the two sexes. But there are three characteristics that can be seen only in a sexual relationship. They include the relationship between A: epi condylar width with AR $(0.471 * *)$ and B: midshaft circumference with max of length

Table I. Characteristics of parameters of 61 Iranian humerus.

\begin{tabular}{lcccc}
\hline & Number & $\begin{array}{c}\text { Minimum } \\
(\mathrm{mm})\end{array}$ & $\begin{array}{c}\text { Maximum } \\
(\mathrm{mm})\end{array}$ & $\begin{array}{c}\text { Mean } \pm \\
\text { Deviation }(\mathrm{mm})\end{array}$ \\
\hline MAX of Width / MAX of length x 100(AR) & 61 & 2.71 & 4.08 & $3.47 \pm 0.31$ \\
midshaft circumference & 61 & 5.20 & 7.90 & $6.51 \pm 0.58$ \\
epicondylar width & 61 & 48.00 & 64.00 & $56.72 \pm 4.05$ \\
maximum of length & 61 & 26.90 & 35.60 & $30.75 \pm 1.88$ \\
angle of medial and lateral wall & 61 & 20.00 & 110.00 & $61.04 \pm 17.2$ \\
angle of late ral wall & 61 & 49.00 & 150.00 & $124.30 \pm 16.59$ \\
angle of medial wall & 61 & 32.00 & 109.00 & $63.45 \pm 18.58$ \\
maximum of width & 61 & 0.80 & 1.30 & $1.06 \pm 0.10$ \\
maximum of depth & 61 & 4.30 & 7.50 & $6.11 \pm 0.71$
\end{tabular}


$(0.481 * *)$ in men, and the relationship between epi condylar width and max of length $(0.511 * *)$ in female. From these demarking points, humeri could be identified and sexed correctly.

Table II. Comparison of means of characteristic of parameters of humerus in males and females.

\begin{tabular}{|c|c|c|c|c|c|c|c|c|c|}
\hline & & & emale & & & & Male & & P.value \\
\hline & Number & $\begin{array}{l}\text { Minimum } \\
(\mathrm{mm})\end{array}$ & $\begin{array}{l}\text { Maximu m } \\
\quad(\mathrm{mm})\end{array}$ & $\begin{array}{l}\text { Mean } \pm \text { Std. } \\
\text { Deviation } \\
(\mathrm{mm})\end{array}$ & Number & $\begin{array}{l}\text { Minimu } \\
\mathrm{m}(\mathrm{mm})\end{array}$ & $\begin{array}{l}\text { Maximum } \\
\quad(\mathrm{mm})\end{array}$ & $\begin{array}{c}\text { Mean } \pm \text { Std. } \\
\text { Deviation }(\mathrm{mm})\end{array}$ & \\
\hline $\begin{array}{l}\text { MAX of Width / MAX } \\
\text { of Length _ } 100(\mathrm{AR})\end{array}$ & 26 & 3 & 4 & $3.56 \pm .32$ & 35 & 3 & 4 & $3.40 \pm .29$ & 0.05 \\
\hline midsh aft circumference & 26 & 5.20 & 7.10 & $6.19 \pm .454$ & 35 & 5.70 & 7.90 & $6.76 \pm 567$ & 0.000 \\
\hline epicondylar wid th & 26 & 49.00 & 62.00 & $54.51 \pm 3.77$ & 35 & 48.00 & 64.00 & $58.37 \pm 3.46$ & 000 \\
\hline maximum of length & 26 & 26.90 & 30.40 & $28.99 \pm 1.05$ & 35 & 30.50 & 35.60 & $32.07 \pm 1.14$ & 0.000 \\
\hline angle of lateral wall & 26 & 105.00 & 150. & $125.12 \pm 13.88$ & 35 & 49.00 & 145.00 & $123.69 \pm 18.52$ & 0.742 \\
\hline angle of medial wall & 26 & 34.00 & 89. & $62.38 \pm 18.86$ & 35 & 32.00 & 109.00 & $64.25 \pm 18.61$ & 0.926 \\
\hline $\begin{array}{l}\text { angle of medial and } \\
\text { lateral wall }\end{array}$ & 26 & 25.00 & 110. & $60.80 \pm 18.44$ & 35 & 20.00 & 90.00 & $61.22 \pm 16.54$ & 0.701 \\
\hline maximum of depth & 26 & 4.30 & 7.50 & $5.93 \pm .64$ & 35 & 4.50 & 7.50 & $6.24 \pm 74$ & 0.029 \\
\hline maximum of width & 26 & 0.80 & 1.20 & $103 \pm .10$ & 35 & 0.90 & 1.30 & $109 \pm 0.09$ & 0.094 \\
\hline
\end{tabular}

Table III. Correlation of means of parameters of humerus in male.

\begin{tabular}{|c|c|c|c|c|c|c|c|c|c|}
\hline correlation in male & AR & $\begin{array}{c}\text { midshaft } \\
\text { circumfere } \\
\text { nce }\end{array}$ & $\begin{array}{l}\text { epicondy } \\
\text { lar wid th }\end{array}$ & $\begin{array}{l}\max \text { of } \\
\text { length }\end{array}$ & $\begin{array}{c}\text { angle of } \\
\text { lateral } \\
\text { wall }\end{array}$ & $\begin{array}{c}\text { angle of } \\
\text { medial } \\
\text { wall }\end{array}$ & $\begin{array}{c}\text { angle of } \\
\text { medial and } \\
\text { lateral wall }\end{array}$ & $\begin{array}{l}\max \text { of } \\
\text { depth }\end{array}$ & $\begin{array}{l}\max \text { of } \\
\text { width }\end{array}$ \\
\hline AR & & & $0.471 * *$ & & & & & & $0.922 * *$ \\
\hline midshaft & & & $0.591 * *$ & $.481 * *$ & & & & & \\
\hline $\begin{array}{l}\text { circumference } \\
\text { epicondylar width }\end{array}$ & $0.471 * *$ & $0.591 * *$ & & & & & & & $0.565^{* *}$ \\
\hline max of length & & $0.481 * *$ & & & & & & & \\
\hline angle of medial wall & & & & & & & $-.523 * *$ & & \\
\hline $\begin{array}{l}\text { angle of medial and } \\
\text { lateral wall }\end{array}$ & & & & & & $-.523 * *$ & & $-.359 *$ & \\
\hline $\begin{array}{l}\text { max of depth } \\
\text { materal wall }\end{array}$ & & & & & & & $-.359 *$ & & \\
\hline max of width & $0.922 * *$ & & $0.565^{* *}$ & & & & & & \\
\hline
\end{tabular}

**. Correlation is significant at the 0.01 level (2-tailed). *. Correlation is significant at the 0.05 level (2-tailed).

Table IV. Correlation between means of characteristic of parameters of humerus in female.

\begin{tabular}{|c|c|c|c|c|c|c|c|c|c|}
\hline $\begin{array}{l}\text { Parameters of } \\
\text { humorous }\end{array}$ & $\begin{array}{l}\text { MAX of } \\
\text { Width / } \\
\text { MAX of } \\
\text { Length_100( } \\
\text { AR) }\end{array}$ & $\begin{array}{c}\text { midshaft } \\
\text { circumference }\end{array}$ & $\begin{array}{l}\text { epicondylar } \\
\text { width }\end{array}$ & $\begin{array}{l}\text { max of } \\
\text { length }\end{array}$ & $\begin{array}{c}\text { angle of } \\
\text { lateral } \\
\text { wall }\end{array}$ & $\begin{array}{c}\text { angle of } \\
\text { medial } \\
\text { wall }\end{array}$ & $\begin{array}{c}\text { angle of } \\
\text { medial and } \\
\text { lateral wall }\end{array}$ & $\begin{array}{l}\text { max of } \\
\text { depth }\end{array}$ & $\begin{array}{l}\text { max of } \\
\text { width }\end{array}$ \\
\hline $\begin{array}{l}\text { MAX of Width / } \\
\text { MAX of Length } \\
* 100 \text { (FILTER) }\end{array}$ & & & & & & & & & $0.932 * *$ \\
\hline $\begin{array}{l}\text { midshaft } \\
\text { circumference } \\
\text { epicondylar } \\
\text { width }\end{array}$ & & $0.661 * *$ & $0.661 * *$ & $\begin{array}{l}0.511 * \\
*\end{array}$ & & & $0.401 *$ & & $0.416^{*}$ \\
\hline max of length & & & $0.511 * *$ & & & & & & $0.512 * *$ \\
\hline $\begin{array}{l}\text { angle of lateral } \\
\text { wall }\end{array}$ & & & & & & $0.488^{*}$ & & & \\
\hline $\begin{array}{l}\text { angle of medial } \\
\text { wall }\end{array}$ & & & & & $0.488 *$ & & $-.498 * *$ & $0.409^{*}$ & \\
\hline $\begin{array}{l}\text { angle of medial } \\
\text { and lateral wall } \\
\text { max of depth }\end{array}$ & & & & & & $\begin{array}{l}-.498^{* *} \\
0.409 *\end{array}$ & $-.471 *$ & $-.471 *$ & \\
\hline max of width & $0.932 * *$ & & $0.416^{*}$ & $0.512 *$ & & & & & \\
\hline
\end{tabular}

**. Correlation is significant at the 0.01 level (2-tailed). *. Correlation is significant at the 0.05 level (2-tailed). 


\section{DISCUSSION}

The existing literature and the sex estimation equations them propose are derived from three different contexts of skeletal remains. The first group consists of human skeletal remains obtained from archaeological excavations. The sex determination of the specimens was estimated by using morphological or visual methods, and then, based on these materials, the sex determination formulas were developed. In the second group, there are the studies focused on dry skeletons, with known sex. The third group consists of radiographic films and the measurements taken from them (Blackless et al. 2000).

For the second group we collected 61 humerus bones from the department of anatomy and measured 10 parameters of these bones that the specifications in the method described above in method and material paragraph.

In this study we found in men positive correlation between AR and epicondylar width $\left(0.471^{* *}\right)$ and midshaft with length of humerous $\left(0.481^{* *}\right)$ that don't have these parameters correlation in female. And conversely we found in female positive correlation between medial and lateral angle with mid shaf $\mathrm{t}$ circumference $\left(0.488^{* *}\right)$ and width of epicondylar and maximum of length $\left(0.511^{* *}\right)$ and medial angle with medial \&lateral angle $(0.498 * *)$ and maximum width with length of humerous $(0.512 * *)$ that don't have these parameters correlation in male. This result reflects the difference between men and women humerus bone dry. It was not found in another study, and we may can make this difference clear sexing.

The observations of sexual differences in the various parameters are shown in comparative Tables IIII. We found that all size of parameters of humerus are greater in men than women except AR index (ratio width /length*100). In comparative of various research, our results are similar of sexual differences in the various parameters. Atamtürk et al. (2010) reports length of humerus in male 57.67, 60.17 in right and left respectively. Hughes reports that humerus is wider in males.

In Lokanadham et al. (2013) comparison of length of humerus of his study with other studies to increase the accuracy in the sex determination, the technique of multi variety analysis was applied. It was found that percentage of humeri that could be sexed correctly was increased. In fact $97 \%$ right and $96.5 \%$ left male humeri and $97.5 \%$ right and $91 \%$ left female humeri could be sexed accurately (Lokanadham et al.).
Sex differences in humeral shape are established prior to puberty is supported by various studies in which greater humeral width was seen in prepubertal boys compared to girls (Patil et al., 2011). compared to Singh and et al., found length from age 3 years until the time of pubertal growth acceleration in females (Palacios-Vargas \& CastañoMeneses, 2009). According Kranito et al., study proved that men have shorter humerus shaft than women humerus shaft (Kranioti \& Michalodimitrakis, 2009). Morphometric of distal segments of humerus is very important because of its sexual dimorphism and humerus is subjected to greater functional stress (Soni et al., 2013). Scan et al. found that the most effective single dimension, as determined by the direct discriminate analysis, was the vertical head diameter in the Chinese $(81 \%)$ and epicondylar breadth in the Japanese and Thai populations $90 \%$ and $93 \%$ respectively (Is, can et al., 1998). That our results showed that epicondylar breadth is difference in male and female that is similar with their founded. Soni et al. reports the most dimorphic single parameter on the basis of discriminant analysis was epicondylar width, with an accuracy of $80 \%$ in males and $87.5 \%$ in females and the combination of epicondylar width and vertical head diameter of the shaft provided better results, with $85 \%$ accuracy in males and $90 \%$ accuracy in females.

Robinson \& Bidmos (2009) got 72-95.5\% accuracy in their study on the skulls and humeri of South Africans. The humeral head diameter was the most common sex discriminator (Robinson \& Bidmos). Kranioti \& Michalodimitrakis studied 168 left humeri by the Osteometric method and they found $92.3 \%$ accuracy in determining the sex and found that the single most effective $(89.9 \%)$ dimension was the vertical head diameter of the humerus. Kranioti \& Michalodimitrakis studied 168 left humeri by the Osteometric method and they found $92.3 \%$ accuracy in determining the sex and found that the single most effective $(89.9 \%)$ dimension was the vertical head diameter of the humerus. Vance \& Steyn (2013) research utilized 608 individuals from South Africa (420 men, 188 women) to conduct a blind nonmetric determination of sex from three features of the distal humerus: olecranon fossa shape, angle of the medial epicondyle, and trochlear extension. With all features combined, black and white South Africans were categorized successfully as either male or female $75.5 \%$ (77\% accuracy rate for females, $74 \%$ accuracy rate for males). This classification rate is lower than what was found in previous studies, but suggests that characteristics of the distal humerus are still quite valuable when estimating skeletal sex. More research is needed to assess reasons for the differential expression of these traits in different populations and to determine whether the method is no population specific (Vance \& Steyn; Pendro et al., 2018). 
ACKNOWLEDGEMENTS. Thanks to the Student Research Committee and the adjutancy of research at Arak University of Medical Sciences

HAMZEHTOFIGH, M.; BAYAT, P. \& RAHIMIFAR, R. Determinación del sexo a partir del hueso del húmero en casos iraníes Int. J. Morphol., 37(4):1370-1374, 2019.

RESUMEN: La determinación del sexo a partir de los huesos es de vital importancia en los estudios antropológicos y en los casos médico-legales. El presente estudio se centró en las mediciones del húmero y en evaluar las diferencias de sexo presentes en la morfología a través del análisis estadístico. En nuestra investigación, se estudiaron 61 húmeros adultos secos ( 35 hombres y 26 mujeres). Los huesos dañados fueron excluidos del estudio. Cada húmero se midió para 10 parámetros; las mediciones se realizaron utilizando un calibrador deslizante como está descrito en textos de antropología y estudios anteriores. Los datos osteométricos del húmero se analizaron estadísticamente y se compararon ambos sexos. Se aplicaron pruebas estadísticas a los datos métricos obtenidos para evaluar si las diferencias entre las medias de cada parámetro eran estadísticamente significativas entre hombres y mujeres. Se observó que existen parámetros más discriminatorios para la identificación del sexo a partir del húmero. En este estudio, encontramos en los hombres correlaciones positivas entre AR y ancho epicondilar $(0,471 * *)$ y vástago medio con la longitud de del húmero $(0,481 * *)$ que no tienen esta correlación de parámetros en mujeres. Además, encontramos correlaciones positivas entre mujeres: ángulo medial y lateral con circunferencia del eje medio $\mathrm{t}\left(0,488^{* *}\right)$ y ancho epicondilar y longitud máxima $\left(0,511^{* *}\right)$ y ángulo medial con ángulo medial y lateral $\left(0.498^{* *}\right)$, y ancho máximo con longitud de húmero $(0.512 * *)$ no se observaron estos parámetros de correlación en el hombre. En estudios anteriores, los autores no analizaron la relación entre la longitud humeral total y las medidas de los segmentos con las posibles diferencias entre la población agrupada por sexo. Esto se podría deber a la diferencia genética, nutricional y socioeconómica en los individuos o la hipocomunidad en el húmero femenino y la hiper masculinidad en el húmero de los hombres.

PALABRAS CLAVE: Análisis de la determinación del sexo; Húmero; Antropometría.

\section{REFERENCES}

Atamtürk, D.; Akçal, M. A.; Duyar, I ' \& Mas, N. Sex estimation from the radiographic measurements of the humerus. Eurasian J. Anthropol., 1(2):99-108, 2010.

Blackless, M.; Charuvastra, A.; Derryck, A.; Fausto-Sterling, A.; Lauzanne, K. \& Lee, E. How sexually dimorphic are we? Review and synthesis. Am. J. Hum. Biol., 12(2):151-66, 2000.

Iscan, M. Y.; Loth, S. R.; King, C. A.; Shihai, D. \& Yoshino, M. Sexual dimorphism in the humerus: a comparative analysis of Chinese, Japanese and Thais. Forensic Sci. Int., 98(1-2):17-29, 1998.

Kothandaraman, U.; Lokanadham, S. \& Raj, P. A. Maximum length of the humerus - Major discriminative variable in sexual dimorphism. Int. J. Health Sci. Res., 4(8):127-31, 2014.
Kranioti, E. F. \& Michalodimitrakis, M. Sexual dimorphism of the humerus in contemporary Cretans--a population-specific study and a review of the literature. J. Forensic Sci., 54(5):996-1000, 2009.

Kshirsagar, S.; Chavan, S.; Makhani, C. \& Kamkhedkar, S. Sexual dimorphism of humerus: a study in Marathwada region. Indian J. Forensic Med. Pathol., 2:145-51, 2009.

Liu, W. Sex discriminant analysis of long bones of upper limb. Acta Anthropol. Sin., 3:231-9, 1989.

Lokanadham, S.; Khaleel, N. \& Raj, A. Morphometric analysis of humerus bone in Indian population. Sch. J. App. Med. Sci., 1(4):288-90, 2013.

Palacios-Vargas, J. G. \& Castaño-Meneses, G. Importance and evolution of sexual dimorphism in different families of Collembola (Hexapoda). Pesq. Agropec. Bras., 44(8):959-63, 2009.

Patil, G.; Kolagi, S. \& Ramadurg, U. Sexual dimorphism in the humerus: A study on South Indians. J. Clin. Diagn. Res., 5(3):538-41, 2011.

Pendro, T. S.; Singh, B. K.; Rastogi, A. K. \& Dadu, S. K. A study about sex determination from distal epiphysiseal measurements ofadult dry humerus bone-in central India (Indore) population. J. Forensic Med. Toxicol., 35:22-31, 2018.

Robinson, M. S. \& Bidmos, M. A. The skull and humerus in the determination of sex: reliability of discriminant function equations. Forensic Sci. Int., 186(1-3):86.e1-5, 2009.

Soni, G.; Dhall, U. \& Chhabra, S. Determination of sex from humerus: discriminant analysis. Aust. J. Forensic Sci., 45(2):147-52, 2013.

Steyn, M. \& Iscan, M. Y. Sex determination from the femur and tibia in South African whites. Forensic Sci. Int., 90(1-2):111-9, 1997.

Steyn, M. \& Iscan, M. Y. Sexual dimorphism in the crania and mandibles of South African whites. Forensic Sci. Int., 98(1-2):9-16, 1998.

Vance, V. L. \& Steyn, M. Geometric morphometric assessment of sexually dimorphic characteristics of the distal humerus. Homo, 64(5):329-40, 2013.

Corresponding autor:

Parvindokht, Bayat

Department of Anatomy

Faculty of Medicine

Arak University of Medical Sciences

Arak

IRAN

Email: Dr.bayat@Arakmu.ac.ir

Received: 25-04-2019

Accepted: 24-06-2019 